\title{
Traumas e travessias: a alteridade ameríndia e as fronteiras simbólicas da nação
}

Rita Olivieri-Godet ${ }^{1}$

\author{
Nosso encontro - ele pode começar agora, pode começar daqui a um \\ ano, daqui a dez anos, e ele ocorre todo o tempo.
} Ailton Kernak, "O eterno retorno do encontro".

\section{O apagamento do extermínio e o mito da mestiçagem na forma- ção da nação brasileira}

O presente ensaio propõe-se a abordar elementos de uma "estética dos vestígios" a partir do enfoque da figuração da alteridade ameríndia em textos ficcionais que exploram questões relativas a memória, esquecimento e silêncio, tecendo relações entre o passado histórico e o presente. No corpus heterogêneo da literatura brasileira contemporânea, a produção que interpela as origens da intolerância na percepção da alteridade ameríndia e o lugar que os povos ameríndios ocupam na sociedade brasileira atual não pode ser negligenciada. São obras que buscam resgatar a memória histórica desses povos, geralmente ignorada nas diversas tentativas de interpretação da nação.

Como constata Gérard Bouchard, a versão oficial da história do Brasil não investe na representação da memória longa. Em vez disso, o que se construiu foi o simbolismo de um imaginário nacional que projeta o início dessa coletividade nova com a chegada dos europeus, insistindo "sobre a mestiçagem precoce que fundiu as três raças fundadoras para criar uma entidade muito diversa" (Bouchard, 2001, p. 382, tradução nossa). Na contramão desse processo, escritores brasileiros contemporâneos travam uma verdadeira batalha em prol de uma reconfiguração do imaginário nacional ao se apropriarem da historicidade dos povos ameríndios. Procuram, dessa maneira, sondar os vestígios oriundos do passado, resgatando a história e preservando a memória desses povos, chamando a atenção para o legado que subsiste no presente, vítima, muitas vezes, do processo de denegação. Testemunhas de uma época marcada pela coexistência de culturas distintas nas sociedades pós-modernas, esses escritores

\footnotetext{
${ }^{1}$ Doutora e pós-doutora em teoria literária e literatura comparada. Professora titular de literatura e cultura brasileiras na Université Rennes 2, Rennes, França. E-mail: rgodet@9online.fr.
} 
dedicam-se, em suas obras, a interpretar a experiência do confronto entre culturas ameríndias e a imposição do modelo de cultura ocidental, experiência compartilhada por outras nações americanas.

No Brasil, criou-se um imaginário conciliador do processo de fundação da nação, baseado na figuração de um território integrador, pacificado e unido no qual evoluem as três principais matrizes étnicas cujas relações são descritas segundo uma ótica que "naturaliza" o processo de mestiçagem. Ao se referir aos mitos fundadores da nação brasileira, Marilena Chauí identifica, entre eles, o da unidade social imaginária que a própria ideia de nação impõe (Chauí, 2000). Isso explica o fato de que a história dos confrontos no período de expansão da colonização e do Estado recémindependente (final do século XVIII e primeira metade do século XIX) tenha sido apagada do imaginário de construção da nação e, que em seu lugar, tenha surgido a imagem inaugural conciliadora da "descoberta".

Parece-nos que a diferença substancial entre a Argentina e o Brasil, no que diz respeito ao tratamento reservado aos povos indígenas, reside mais na construção do imaginário de fundação das respectivas nações do que propriamente nas políticas indigenistas adotadas por seus governantes. Os estudos recentes de historiadores mostram que, nos séculos XVIII e XIX, a política indigenista brasileira seguia uma orientação semelhante à desenvolvida pela Argentina, reservando aos índios que não se submetiam aos seus ditames, como os Botocudos' ${ }^{2}$, a mesma sorte que o governo argentino reservava aos povos ameríndios habitantes do Pampa. Maria Hilda Paraíso, ao referir-se à política indigenista que predominou a partir da Carta Régia de 1798, "fruto da pressão de latifundiários insatisfeitos com a maneira 'branda' como os índios eram tratados" (Paraíso, 1992, p. 416), mostra claramente o sentido das leis e os interesses escusos dos governantes e colonos, além de evocar as medidas adotadas para pôr em prática essa política, como a construção de quartéis e a mobilização de homens treinados para combater os Botocudos na região do sul da Bahia e na fronteira entre Espírito Santo e Minas Gerais.

Embora o Brasil compartilhe com a Argentina um ideário positivista que guiou o processo de fundação da nação, o discurso que acompanhou sua inserção na modernidade é ambíguo na medida em que projeta a

\footnotetext{
2 O estudo de Maria Hilda Paraíso (1992) “Os botocudos e sua trajetória histórica” é fundamental para a compreensão da história desse povo e revelador da violência que lhe foi infligida. No romance O rastro do Jaguar, Murilo Carvalho revisita a história dos Aimoré/botocudos. Ver, aqui mesmo, nossos comentários sobre esse romance. Para uma análise crítica mais desenvolvida, remetemos ao nosso artigo "Histórias de índios entre assimilação e resistência: O rastro do Jaguar" (Godet, 2010a).
} 
construção de uma identidade nacional mestiça, ainda que, evidentemente, a referência maior continue sendo a do modelo ocidental ${ }^{3}$. Marilena Chauí demonstra muito propriamente como, contrariamente à retórica da mestiçagem, a sociedade brasileira disfarça uma tendência autoritária a homogeneizar as diferenças. Vários outros estudiosos dão ênfase à existência de "uma singular cultura política brasileira de 'conciliação'" que, no caso dos índios, como assinala David Treece $\left(2008\right.$, p. 11) ${ }^{4}$, contrasta com o brutal genocídio que os vitimaram durante mais de cinco séculos. Esse autor considera que a tradição de pensamento nacionalista no Brasil criou uma "mitologia integracionista (que) invocou repetidamente sua (dos índios) assimilação na sociedade dominante como a pedra de toque para uma história pacífica de integração política, social e econômica" (Treece, 2008, p. 11). A política dual colonialista - baseada nas ações militar e missionária e que, segundo Treece, dividiu “a população indígena entre aqueles determinados a resistir (os assim chamados tapuias) e aqueles que concordavam em abandonar seus costumes tribais e submeter-se ao regime dos povoamentos jesuítas" (Treece, 2008, p. 50-51), ou seja, uma política que preconizava a assimilação ou o extermínio - continuou a ser praticada no reino de Dom João VI (as guerras justas que autorizavam o extermínio de tribos que recusavam a civilização) e até mesmo após a independência. Essa política alimenta os estereótipos do índio dócil e receptivo à "civilização" que se contrapõe ao do selvagem rebelde e canibal, estereótipos que se fazem presentes nos diversos territórios americanos. Como observa Treece, "há uma forte similaridade entre a categorização

\footnotetext{
3 Apesar do predomínio, no Brasil, de um discurso de conciliação, alguns intelectuais assumiram abertamente, de maneira semelhante às elites argentinas, uma postura violenta contra os índios, a exemplo do historiador Varnaghen, que, em 1851, de acordo com o estudo de David Treece, "advogou um implacável uso da força, com a reintrodução das bandeiras coloniais - expedições pioneiras escravistas como fim de sujeitar o índio ao controle do branco e liberar suas terras para a exploração por colonos brasileiros e imigrantes” (Treece, 2008, p. 29). Em nome da ameaça que os índios representam para a civilização, por serem considerados por Varnhagen como obstáculos ao progresso, o historiador defende o direito de tratá-los como inimigos. No fragmento citado a seguir, de autoria de Varnhagen, nota-se como o pensamento do historiador está em sintonia com os discursos produzidos pelas elites argentinas do século XIX: "Mas, se os considerarmos estranhos ao pacto social, se os reputarmos uma nação forasteira que nos molesta e prejudica, temos todo o direito de conquistá-los, e não há direito de conquista mais justo que o da civilização sobre a barbaria” (Varnhagen apud Treece, 2008, p. 200). Essa sintonia fica ainda mais evidenciada no prefácio “Os índios perante a Nacionalidade Brazileira”, que escreveu para sua História Geral do Brasil (1854).

4 David Treece é autor do excelente ensaio Exilados, aliados, rebeldes. O movimento indigenista, a política indigenista e o Estado-nação imperial, no qual se dedica ao estudo da representação dos índios desde o início da colonização até o final do século XIX. Destaca-se o estudo sobre o indianismo romântico brasileiro, relacionando-o com o contexto histórico de formação do Estado-nacional, a partir de um corpus que inclui, além dos textos canônicos, obras menores e até desconhecidas.
} 
dualista de tapuias e tupis e a estereotipia étnica de caribes e arawakcs na América espanhola em seguida à viagem de Colombo pelo Caribe" (Treece, 2008, p. 55) .

\section{Os ameríndios na ficção brasileira contemporânea}

O enfoque deste artigo está voltado para uma vertente da literatura contemporânea brasileira que explora a dimensão do estranhamento em relação à alteridade indígena no interior da nação, articulando-a às questões de ancestralidade. Remontar o fio do passado histórico para tentar desentranhar os elementos que possam tornar inteligível o processo de formação do território nacional é um dos seus objetivos. Contrariamente ao imaginário nacional brasileiro produzido pelas instituições, algumas obras perseguem a representação de uma memória longa. Instauram uma dimensão propriamente histórica ao questionamento das relações interculturais, na medida em que propõem revisitar a formação do Estadonação, contribuindo para a reflexão sobre a origem de preconceitos que continuam a marginalizar as culturas dos povos indígenas e a alimentar os conflitos atuais. Dedicam-se, assim, ao exame da noção de "nacional" que se processa, como assinala José Luís Jobim, "em relação aos grupos constituídos dentro do território que o delimita e às normas criadas para regulá-lo" (Jobim, 2006, p. 187).

Desse modo, uma das possibilidades trilhadas por romances que tomamos como referência neste trabalho consiste em interpelar a formação da consciência nacional e das identidades coletivas, explorando as relações entre as coletividades novas do Novo Mundo e o poder das metrópoles, examinando a forma como essas coletividades evoluíram e os modelos que erigiram em relação ao Velho Mundo, num percurso que hesita entre continuidade e ruptura (Bouchard, 2001). Gérard Bouchard toma como ilustração da hesitação entre continuidade e ruptura, no percurso de construção das coletividades novas, um estudo realizado por E. E. Burns sobre 63 historiadores do século XIX. Burns demonstra que "a referência europeia e a rejeição da indianidade constituíam os traços dominantes da historiografia latino-americana dessa época", chamando a atenção para o fato de que esses traços continuam visíveis no período atual (Bouchard, 2001, p. 203).

\footnotetext{
${ }^{5}$ David Treece demonstra como o contato entre missionários e índios orientou a política da assimilação ou extermínio, gerando "o estereótipo do tupi receptivo e civilizado e do tapuia intratável e selvagem” (Treece, 2008, p. 253). 
Do ponto de vista do imaginário literário de fundação da nação brasileira, a figura mítica do índio está presente nos textos românticos que reivindicam a emancipação da literatura nacional. Um século depois, o Modernismo de 22 atualiza o questionamento identitário e contribui para a formação de um imaginário literário nacional, por meio de uma visão paródica que transforma o índio idealizado dos românticos no anti-herói antropófago e rebelde, valorando positivamente a imagem do selvagem canibal. O final do século XX e o início do século $\mathrm{XXI}^{6}$ desponta, talvez, como um terceiro momento, após o nacionalismo romântico e a antropofagia modernista, em que a literatura incorpora, de maneira significativa, a figuração dos ameríndios, independentemente do fato de esses textos não surgirem no âmbito de uma "escola literária". Esse tipo de produção literária põe em questão as fronteiras culturais internas à nação, denunciando o processo de marginalização dos ameríndios transformados em "estrangeiros de dentro". Recorre à memória histórica para recuperar o processo de espoliação que vitimou essas populações.

A data comemorativa dos "500 anos" colabora para manter viva a temática em torno da questão indígena, motivando o aparecimento de uma série de textos que revisitam, em épocas e contextos diversos, as relações entre os povos indígenas e a sociedade ocidental. A conjuntura favorece $o$ questionamento sobre o percurso dos conflitos entre povos distintos que estão na origem da formação cultural brasileira. Desde finais dos anos 1990 até a primeira década do século XXI, vários romances exploram essa temática: Breviário das terras do Brasil: uma aventura nos tempos da inquisição (1997), de Luiz Antonio de Assis Brasil; A Majestade do Xingu (1997) e Éden-Brasil (2002), de Moacyr Scliar; Meu querido canibal (2000), de Antônio Torres; Terra Papagalli: narração para preguiçosos leitores da luxuriosa, irada, soberba, invejável, cobiçada e gulosa história do primeiro rei do Brasil (2000), de José Roberto Torero e Marcus Aurelius Pimenta; Nove noites (2002), de Bernardo Carvalho; Orfãos do Eldorado (2008), de Milton Hatoum; O rastro do Jaguar (2009), de Murilo Carvalho; Yuxin (2009); de Ana Miranda; Meu destino é ser onça (2009), de Alberto Mussa, entre outros.

Alguns desses romances reconstituem a memória histórica a partir de uma leitura crítica da ideologia hegemônica, tendo como pano de fundo a

\footnotetext{
${ }^{6}$ Não cabe aqui nos determos nos detalhes da história da representação literária dos índios no Brasil, tema já abordado em artigos e obras de autoria de Chiappini (2006), Figueiredo (2010), no excelente ensaio de Treece (2008), que estuda as formas de representação dos índios nos textos literários do século XVI ao final do século XIX. Num ensaio ainda inédito, A alteridade ameríndia na ficção contemporânea das Américas (Brasil, Argentina, Québec), retomamos o tema, introduzindo uma perspectiva comparatista, com destaque especial para a segunda metade do século XX e o século XXI.
} 
discussão das relações identidade/alteridade, podendo adotar uma perspectiva épica ou dramática ( $O$ rastro do Jaguar), enquanto outros recorrem à visão paródica-carnavalesca (Éden-Brasil, Terra papagalli...). Outros ainda alternam as duas perspectivas (Meu querido canibal), estratégia que compartilham com romances dos anos 1980 que tematizam a questão indígena, como: A expedição Montaigne, de Antônio Callado; Utopia selvagem, de Darcy Ribeiro; e O feitiço da ilha do pavão, de João Ubaldo Ribeiro. Esses romances de Callado, Darcy Ribeiro e João Ubaldo discutem o projeto de construção de uma nacionalidade brasileira, afastando-se de um elogio ingênuo da mestiçagem para problematizar as relações interétnicas e interculturais, questionando o lugar reservado ao índio nesse processo. Rejeitam a figura mítica do índio romântico, inscrevendo-se na trilha modernista de uma representação paródica do índio. Entre mito e realidade, desencanto e utopia selvagem - "uma incurável nostalgia de um mundo que bem podia ser" (Ribeiro, 1981, p. 188) -, essas obras abraçam a dialética do sério-cômico para falar do espaço marginal que a nação brasileira reserva aos índios, negros e pobres.

Estratégia semelhante adota o escritor amazonense Márcio Souza no romance Mad Maria (1980). O olhar irônico do autor revisita a história da construção da ferrovia Madeira-Mamoré, realizando uma crítica feroz à ideologia do progresso que marginaliza e desestrutura os povos indígenas cujo destino trágico é evocado por meio do índio Joe Caripuna. A reflexão sobre a questão indígena atravessa toda a obra de Márcio Souza. Tanto em romances como $O$ fim do Terceiro Mundo (1990) como na recente trilogia Crônicas do Grão-Pará e Rio Negro (Lealdade, 2001a; Desordem. 2001b; e Revolta, 2005a), o autor encena a difícil coabitação entre as diferentes comunidades culturais, os preconceitos em relação aos povos indígenas, a confiscação de seus direitos e a exploração sexual das jovens mulheres indígenas, recusando uma forma de representação que aprisiona os índios no passado e tecendo um quadro tocante do seu estatuto ao longo da história do país.

Além dos romances, a produção dramática e ensaística de Márcio Souza (Teatro indígena do Amazonas, 1979; Ajuricaba, o caudilho das selvas, 2006; Os índios vão à luta, 1981) completa a dimensão militante de uma obra que luta pela revalorização do estatuto do índio, alimentada por figuras legendárias da memória popular que encarnam a resistência à opressão, como bem observa Brigitte Thiérion (2010, p. 256). É o caso de Ajuricaba, personagem histórico, Tuxaua dos Manau, líder da confederação tribal que, entre 1722 e 1728, reuniu mais de trinta nações do vale do Rio Negro, para combater os portugueses. Além da biografia romanceada 
que escreve sobre Ajuricaba, Márcio Souza dedica-lhe a peça $A$ paixão de Ajuricaba (2005b), numa clara estratégia de transmissão memorial, mantendo viva no presente a história da luta dos manau, grupo aruaque, hoje extinto. O coro assume um discurso de heroicização do personagem a fim de vencer as fronteiras do tempo, perpetuando no presente a atitude de resistência e de contestação do poder.

O texto dramático de Márcio Souza exerce a função de suporte da memória da história de um povo, vítima do extermínio, que se quer transmitir ao presente. A memória como transmissão, o fluxo entre passado e presente, e outros elementos que têm a ver com uma "estética dos vestígios" podem ser observados em cinco das narrativas publicadas, a partir da virada do século, que tomam a figura do ameríndio como instância de alteridade (Patterson, 2004), as quais passaremos a comentar brevemente, em razão da extensão deste texto.

Em Meu querido canibal (2000), Antônio Torres filia-se à visão paródica-carnavalesca para construir seu herói Cunhambebe, recorrendo à ação corrosiva do humor. $\mathrm{O}$ romance inscreve-se bem na tendência da metaficção historiográfica, ao revisitar, segundo o ponto de vista do vencido, a história da Confederação dos Tamoios, organizada para resistir ao invasor, no litoral do atual estado do Rio de Janeiro. Na construção do herói Cunhambebe, o autor filia-se à visão paródica-carnavalesca que emprega a ação corrosiva do humor para interrogar a realidade nacional. Em outros momentos, recorre às narrativas míticas ou ao registro da reportagem, construindo um texto híbrido e provocador na maneira irreverente como desbanca a autoridade de certas fontes literárias e históricas. Iconoclasta, ousa fazer as boas perguntas sobre os interesses políticos e militares do processo de catequização dos índios e o papel que os jesuítas José de Anchieta e Manuel da Nóbrega assumiram nesse processo.

Meu querido canibal busca uma resposta para as origens históricas da invisibilidade do índio no presente. O caráter metalinguístico do discurso põe a nu o processo de desconstrução da institucionalização das fontes históricas sem que, no entanto, isso implique que a memória reconstruída pelo romance seja apresentada como a "memória verdadeira": ela é apenas uma versão possível. Reivindicando abertamente o papel de mediadora na evocação do passado, sempre tensionado ao presente, a experiência histórica, reconstruída pelo narrador-escritor, recorre à imaginação para explorar os contraditórios vestígios que emanam das fontes escritas, ao tempo em que se esforça por descobrir, no presente, os rastros da cultura dos ameríndios que habitavam a região. Além das fontes escritas, o narrador-escritor pede auxílio às fontes vivas da memória, num 
vai-e-vem entre passado e presente, interrogando os ameríndios que atualmente habitam a região de Angra dos Reis - índios Guarani destituídos de seus territórios, transplantados e confinados numa reserva miserável. O romance de Torres aponta as falhas da memória que levam à construção de uma identidade coletiva excludente, denunciando o presente dos "índios restantes" marcado pelo extermínio, pela desterritorialização e pelas condições precárias de assimilação à sociedade nacional.

Em Nove noites (2002), de Bernardo Carvalho, a narrativa também ultrapassa as fronteiras do gênero, misturando fatos históricos, experiência vivida e ficção. $\mathrm{O}$ romance se constrói em torno do enigma da morte do antropólogo norte-americano Buell Quain, da Universidade de Columbia, ex-aluno de Franz Boas, que se suicidou no Brasil, em 1939, aos 27 anos, quando da sua estadia no Xingu com os índios krahô. O texto aponta para a incompreensão mútua entre brasileiros e índios, procurando preencher de forma obsessiva a precariedade do sentido, o enigma da compreensão do Outro.

Documentos escritos e interlocutores vivos constituem as fontes que o escritor-personagem-narrador utiliza para interrogar os vestígios memoriais no seu empenho de atribuir um sentido inteligível ao passado. Reminiscências da memória pessoal do narrador cruzam a tentativa de reconstituição da experiência vivida pelo antropólogo entre os índios Khraô, sondando as causas que o levaram ao suicídio. Tarefa essa, desde o início, voltada ao fracasso, menos pelas pistas fragmentárias da passagem de Buell Quain pelo Brasil, intensificada pela multiplicidade de vozes narrativas que tornam a percepção do real problemática, do que pela própria impossibilidade de perseguir o rastro do ser humano na sua mais recôndita intimidade.

O foco do escritor-personagem-narrador está voltado para Bell Quain. Dessa forma, deslocando para um segundo plano os índios Khraô, o romance opta por uma forma narrativa que confere expressividade ao lugar marginal que a sociedade brasileira reserva ao índio, o não valor de sua cultura, a recusa em considerá-lo como sujeito autônomo. $\mathrm{O}$ índio surge então como o estrangeiro de dentro. Em Nove noites, a adoção pelo escritor-personagem-narrador do ponto de vista do brasileiro urbano, branco e letrado, prisioneiro de suas próprias referências identitárias, torna evidente a rejeição das marcas das culturas indígenas, para significar o diálogo abortado entre o Brasil "branco" e urbano e o Brasil dos povos autóctones. O fluxo entre a recomposição da memória do passado e a experiência do presente inscreve a ausência de negociações identitárias equilibradas entre a sociedade brasileira e as culturas indígenas num período 
que abrange uma dimensão temporal moderna e pós-moderna da história do Brasil (dos anos 1930 ao início do século XXI). Decorre daí a visão trágica de uma civilização em via de extinção, que dá lugar às figurações de índios aculturados, decadentes, reduzidos a objetos exóticos ou a objetos de estudo, visão que o romance expõe e denuncia.

Contrariamente à rejeição que o narrador de Nove noites manifesta em relação às marcas da cultura indígena, na obra de Milton Hatoum Orfãos do Eldorado (2008), a experiência da alteridade ameríndia gera uma espécie de fascinação pelo Outro no único sujeito da enunciação, o personagemnarrador Arminto Clodovil. Nesse texto, Hatoum examina a problemática coabitação entre a cultura tapuia e a modernidade transplantada, revisitando mais uma vez o imaginário de uma cidade híbrida, Manaus, construída a partir de múltiplas interações culturais. Em Orfãos do Eldorado, a ambiguidade da narrativa decorre das inter-relações entre mito e história e da complexa viagem ao passado através da memória do narrador.

Em um ensaio de 2009, chamávamos a atenção para o fato de que a indagação sobre a dinâmica das relações interculturais realizada pela obra de Miltom Hatoum, cruzando experiência vivida, memória e mito, não escamoteia os aspectos traumáticos dos possíveis entrelaçamentos. $\mathrm{O}$ personagem-narrador Arminto Clodovil, à semelhança de outros narradores de Hatoum, ocupa um lugar fronteiriço atravessado por imaginários culturais diversos. Apesar de o ponto de vista adotado corresponder ao do brasileiro que bebeu na fonte da cultura ameríndia, Hatoum não adere à ideologia da mestiçagem como elemento consubstancial à nação brasileira. Em vez disso, expõe as fraturas do processo, denunciando a construção dramática desse espaço ambivalente, nas dimensões individual e coletiva. A nostalgia de um mundo perdido, que permeia a narrativa, propulsiona o narrador a investigar os vestígios do passado, obrigando-o a posicionar-se entre o luto e a herança. Ancorado numa história familiar que tem como pano de fundo elementos importantes da história regional, o texto romanesco dedica-se ao entrelaçamento da memória pessoal e da memória coletiva para melhor explorar os vestígios da ideologia colonial, num espaço urbano híbrido e violento. A escrita do romance inaugura uma "zona de tensões" (Harel, 2007, p. 108), exibindo a dificuldade e as contradições da construção da "habitabilidade psíquica" do personagem-narrador, representante da elite decadente, e de outros sujeitos - os ameríndios e os pobres brasileiros precariamente inseridos na sociedade urbana -, herdeiros de visões do paraíso, vítimas de uma modernidade transplantada, abandonados à miséria e à orfandade. 
Outro romance articula mito e história para evocar os sistemas das culturas indígenas num contexto de confronto com o modelo ocidental. Em O rastro do Jaguar (2009), de Murilo Carvalho, defrontamo-nos com a inserção do mito da "Terra sem Males" como mola propulsora da narrativa. O romance realiza uma minuciosa reconstrução histórica do processo de desterritorialização de dois grandes povos indígenas das Américas, os Botocudos (denominação genérica dos Aimoré, da linhagem linguística Macro-Jê) e os Guarani. Situa o presente da narração no contexto conturbado do século XIX, período de formação das nações latino-americanas, marcado por grandes guerras (como a do Paraguai) e "pequenas" guerras ignoradas pela versão oficial da história, mas que foram, no entanto, determinantes no processo de deslocamento, assimilação e extermínio dos povos indígenas. O objetivo é o de recuperar os traços dessa história, remontando no tempo para encontrar os vestígios de uma filiação desses povos ao território e de sua progressiva desterritorialização, entrelaçando a história da formação da nação brasileira com as das nações indígenas e conferindo uma dimensão continental ao embate dos povos ameríndios.

Em torno dos Botocudos, praticamente extintos, construiu-se a imagem de ferozes selvagens que contrasta com o perfil dócil e submisso geralmente atribuído aos Guarani. Fundamentando-se numa ampla pesquisa sobre a história desses povos, o primeiro romance do jornalista Murilo Carvalho, ganhador do prêmio Leya 2008, tem, entre outros, o mérito de considerar as singularidades históricas e antropológicas de povos distintos cujas diferenças tendem a ser amalgamadas, a começar pela atribuição da denominação genérica de "índios". Contribui, dessa maneira, para a recuperação de uma memória própria aos Botocudos-Aimoré e aos Guarani. Explora o entrelaçamento entre relato ficcional e relato mítico, destacando aspectos comuns às mitologias ocidentais e indígenas. Revisitando o caráter messiânico do mito do jaguar, a ficção aproxima os relatos bíblicos e Guarani, num procedimento semelhante ao que encontramos em Meu querido canibal, cujo texto estabelece um paralelo entre o Gênesis e o mito da criação do mundo, segundo a mitologia dos Desana ${ }^{7}$.

Essa passarela entre dois mundos é igualmente trabalhada a partir de personagens fronteiriços, como o próprio narrador e o índio guarani Pierre, educado na França, que volta para assumir a liderança de seu povo. Contrariamente ao personagem Avá-Isaías, do célebre romance Maíra (1984 [1976]), de Darcy Ribeiro, personagem cindido e impossibilitado de assumir sua função de tuxaua à qual estava predestinado, Pierre

\footnotetext{
${ }^{7}$ Um dos povos indígenas da região do rio Negro.
} 
aceita o papel de líder que seu povo lhe confere, encarnando o Jaguar que guiará os Guarani até a "Terra sem Males".

Indo de encontro à visão etnocêntrica que considera os povos indígenas como "sociedades 'frias', sem história", visão contra a qual a historiadora Manuela Carneiro da Cunha se insurge (1992, p. 11), O rastro do Jaguar mostra a continuidade da política colonial, durante o período de formação das nações. Do vale do Jequitinhonha ao vale do Iguariaçá, os ameríndios que aí habitavam, respectivamente, os Botocudos e os Guarani, transformam-se em vítimas da violência da expansão territorial.

Meu destino é ser onça (2009), de Alberto Mussa, é outro exemplo de narrativa contemporânea que elege a alteridade ameríndia para refletir sobre as relações interculturais. Retoma o mito da "Terra sem Males" para explorá-lo numa direção completamente diferente da seguida por Murilo Carvalho. Diante da impossibilidade de reconstituir a versão original do mito - a "memória verdadeira" -, posto que sempre mediada por discursos outros, o narrador-escritor assume plenamente a função de mediador entre as fontes do passado e a reconstrução que opera no presente.

Em Meu destino é ser onça, o texto híbrido de Alberto Mussa mescla diversos gêneros, como ensaio, narrativas míticas e teoria, inaugurando uma arqueologia da escrita, bem ao gosto do autor de O enigma de Qaf. O escritor parte dos relatos míticos dos Tupinambá, narrado por André Thévet, confrontando-os com outras fontes e produzindo assim seu próprio texto, "um texto novo, em português, que corresponde a um possível original tupi" (Mussa, 2009, p. 27). A mescla de gêneros diversos, o processo de canibalização das fontes, tem algo em comum com a experiência inaugurada pelo texto de Meu querido canibal, inclusive no que diz respeito ao aproveitamento da versão anotada de André Thévet sobre a cosmogonia dos Tupinambá, embora a obra de Mussa evolua num sentido diferente.

As leituras canibalizadas de Mussa produzem uma constante reescritura e reformulação das histórias de uma tradição de textos sobre a cosmogonia Tupinambá que passam de geração em geração. Segundo a estudiosa Maria Inês de Almeida (2009), esse recurso coloca em evidência a dimensão coletiva da experiência literária que é um dos elementos característicos de uma compreensão indígena da literatura. Não se trata, para o autor de Meu destino é ser onça, de restituir o mito original dos Tupinambá, mas de assumir a impossibilidade de fazê-lo, embora não se exima da tentativa de propor uma interpretação.

A escrita literária se quer um arquivo vivo, nutrindo-se das fontes da história para imaginar outros significados possíveis. Num dos capítulos 
desse livro, desconcertante e provocador, intitulado "No rastro dos tupinambá", Mussa chama a atenção para os 11 mil anos de ocupação humana da Amazônia brasileira, inscrevendo a história nacional numa forma de representação que privilegia a memória longa, na medida em que se apropria da historicidade dos povos ameríndios: "Não sei o que ainda é necessário fazer para que as pessoas compreendam isso - que não estamos aqui faz apenas cinco séculos, mas há uns 15 mil anos" (Mussa, 2009, p. 22).

\section{Travessias de fronteiras e contemporaneidade das culturas ameríndias}

Podemos inferir, a partir das obras evocadas e dos comentários precedentes, que a figuração literária da alteridade ameríndia tem uma presença de relativo destaque na heterogeneidade da produção contemporânea do Brasil. Essa presença está relacionada com uma preocupação maior que atravessa a reflexão sobre a contemporaneidade e que tem a ver com questões que dizem respeito às travessias de fronteiras culturais. O questionamento em torno da problemática das culturas em contato nas sociedades pós-modernas termina por conduzir a uma revisão da memória historiográfica da nação, entrelaçando história e mito para denunciar os estereótipos construídos ao longo dos conflitos entre formações culturais diversas e projetar outras modalidades possíveis de inter-relações culturais.

Durante quase dois séculos, os projetos nacionais das nações americanas fundamentaram-se no objetivo de constituir nações homogêneas e mestiças (Gros, 2006, p. 263). Nessa conjuntura, observa Christian Gros, imperava a política assimilacionista das populações indígenas, cuja finalidade era então "nacionalizar os índios". A partir dos anos 1980, o processo de redemocratização e a mobilização política dessas comunidades fizeram com que as novas constituições adotadas nas Américas evoluíssem no sentido de reconhecer o caráter multiétnico e multicultural dessas nações, reconhecendo as populações indígenas e afrodescendentes como entidades distintas. Christian Gros interroga a razão da transformação radical dos projetos nacionais da América do Sul (mas não somente) que passam do objetivo de "nacionalizar o índio" ao "de etnicizar a nação". O autor chama a atenção para a necessidade de as novas políticas multiculturalistas conduzirem a uma "redistribuição de poder e um aprofundamento da cidadania", o que, de fato, não vem acontecendo, ou se esboça timidamente em países como o Brasil. A mudança de orientação inaugura uma "revolução simbólica", propõe um novo imaginário de reconhecimento 
identitário. No entanto, os estados nacionais ainda não foram capazes de superar o abismo entre as novas promessas de inclusão e a marginalização socioeconômica à qual essas populações continuam a ser condenadas, igualmente vítimas, como outros setores da população, de uma política econômica orientada pelas elites globalizadas (Gros, 2006, p. 270).

As obras enfocadas estão embasadas na ideia de um projeto inclusivo no que diz respeito à construção da cidadania no interior dos estados nacionais, além de possibilitarem uma reflexão sobre o significado da "americanidade" no âmbito do cosmopolitismo pós-moderno que favorece a produção simbólica de culturas fronteiriças de maneira a superar a cisão entre tradição e modernidade (Côté, 2007). Ao operar o questionamento da marginalização dos ameríndios pela sociedade brasileira, elas contribuem para superar as fronteiras simbólicas internas herdadas do processo de formação da nação. Deslocam o imaginário que reserva aos povos indígenas o lugar marginalizado de "estrangeiro de dentro", impulsionando, ao modo delas, nas nuanças de seus universos específicos, a reconfiguração da sensibilidade contemporânea.

As culturas ameríndias inscrevem-se na contemporaneidade das nações americanas, contemporaneidade marcada pela heterogeneidade de culturas que necessitam de um "espaço habitável" (Harel, 2007), um espaço democrático no qual elas possam coexistir sem estarem hierarquicamente submetidas ao modelo da cultura majoritária. Isso não quer dizer que, na concepção marcadamente estratégica e pragmática de Harel, esse espaço seja isento de conflitos e escape às variantes históricas que determinam as relações de poder. A afirmação da contemporaneidade das culturas ameríndias é uma evidência. Ao mesmo tempo, torna-se necessário relembrar essa evidência, tendo em vista um tipo de representação ainda recorrente na atualidade que aprisiona os povos indígenas no passado, projetando-os numa outra temporalidade sem tecer os laços com o presente, figurando-os enquanto sujeitos efêmeros no presente e destinados a desaparecer no futuro.

A vertente da literatura brasileira contemporânea que aqui nos ocupa rasura esse imaginário procurando adotar o ponto de vista do simbolismo canibal dos Tupinambá que, segundo a interpretação de Eduardo Viveiros de Castro, indica uma "incompletude radicalmente positiva", revelando "a indispensabilidade dos outros, ou a impensabilidade de um mundo sem Outrem" (Viveiros de Castro, 2002, p. 241). Essa perspectiva atravessa a construção das narrativas comentadas, na medida em que seus autores escolhem uma das vítimas historicamente emblemáticas da rejeição do outro - o ameríndio - como personagem central para pensar 
a "indispensabilidade do outro". Dessa forma, posicionam-se contra o olhar etnocêntrico ocidental e recusam o essencialismo identitário, contribuindo para a promoção de novas formas de percepção da Alteridade e de negociações identitárias. Colocam em cena a contemporaneidade do encontro/desencontro entre sistemas culturais distintos e desvelam uma visão de mundo que participa do nosso tempo presente e com a qual precisamos aprender urgentemente a dialogar.

\section{Referências}

ALMEIDA, Maria Inês de (2009). Entrevista a Sérgio Medeiros. Disponível em: <http://txaihunikuin.blogspot.fr/2011/05/entrevista-da-professoramaria-ines-de.html>. Acessado em: 28 set 2012.

BOUCHARD, Gérard (2001). Genèse des nations et cultures du Nouveau Monde. Québec: Boréal Compact.

BRASIL, Luiz Antônio de Assis (1997). Breviário das terras do Brasil: uma aventura nos tempos da Inquisição. Porto Alegre: L\&PM.

CALlADO, Antonio (1982). A expedição Montaigne. Rio de Janeiro: Nova Fronteira.

CARVALHO, Bernardo (2002). Nove noites. São Paulo: Companhia das Letras. CARVALHO, Murilo (2009). O rastro do Jaguar. São Paulo: Leya.

CASTRO, Eduardo Viveiros (2002). A inconstância da alma selvagem - E outros ensaios de antropologia. São Paulo: Cosac Naify.

CHAUÍ, Marilena (1995). "Política cultural, cultura política". Brasil/Brazil: revista de literatura brasileira, n. 13, p. 18-19.

(2000). Brasil: mito fundador e sociedade autoritária. São Paulo: Fundação Perseu Abramo.

CHIAPPINI, Lígia (2006). “O índio na literatura brasileira: de personagem a narrador e autor". Revue Internationale d'études lusophones, n. 1, p. 79-104.

COTE, Jean-François (2007). "Les nouvelles formes de cosmopolitisme dans les Amériques: regards et expressions de la littérature et du droit". Rennes, 28 jun. (Conferência na Universidade de Rennes 2)

CUNHA, Maria Manuela (Org.) (1992). A história dos índios no Brasil. São Paulo: Companhia das Letras, Secretaria Municipal de Cultura, FAPESP.

DANTAS, Beatriz et al. (1992). "Os povos indígenas no Nordeste brasileiro: um esboço histórico". In: CUNHA, Maria Manuela (Org.). A história dos índios no Brasil. São Paulo: Companhia das Letras, Secretaria Municipal de Cultura, FAPESP.

FIGUEIREDO, Eurídice (2007). “A figura do autóctone: territorialidade, alteridade, identidade". In: FIGUEIREDO, Eurídice; PORTO, Maria Bernadette Velloso (Orgs.). Figurações da alteridade. Niterói: EDUFF, ABECAN. 
(2010). Representações e etnicidade: perspectivas interamericanas de literatura e cultura. Rio de Janeiro: 7 Letras.

GODET, Rita Olivieri (2009). “O ameríndio como personagem do outro na literatura brasileira contemporânea: Orfãos do Eldorado e Nove Noites". Revista brasileira de literatura comparada, v. 15. Disponível em: <http://www.abralic. org.br/revista/2009/15>.

(2010a). "Histórias de índios entre assimilação e resistência: O rastro do jaguar". Estudos de literatura brasileira contemporânea, n. 36, p. 175-189.

(2010b). "La poétique de l'altérité et la représentation de l'Amérindien dans la fiction des Amériques". In: GODET, Rita Olivieri (dir.). Ecriture et identités dans la nouvelle fiction romanesque. Rennes: PUR.

(2010c). "Entre discursos: literatura e história em Meu querido canibal". In: NOVAES, Cláudio Cledson; SEIDEL, Roberto Henrique. Espaço nacional, fronteiras e deslocamentos na obra de Antônio Torres. Feira de Santana: UEFS Editora.

GROS, Christian (2006). “Nationaliser l'Indien, ethniciser la nation: l'Amérique Latine face au multiculturalisme". In: GROS, Christian; STRIGLER, Marie-Claude (Dirs.). Être indien dans les Amériques. Paris: Edition de l'Institut des Amériques.

HAREL, Simon (2005). Les passages obligés de l'écriture migrante. Montréal: XYZ. HATOUM, Milton (2008). Órfãos do Eldorado. São Paulo: Companhia das Letras.

JOBIM, José Luís (2006). “Representação da identidade nacional e outras identidades". Gragoatá:, n. 20, p. 185-197.

MUSSA, Alberto (2009). Meu destino é ser onça. Rio de Janeiro: Record.

PATERSON, Janet M. (2004). Figures de l'Autre dans le roman québécois. Montréal: Nota Bene.

PARAISO, Maria Hilda (1992). "Os botocudos e sua trajetória histórica". In: CUNHA, Maria Manuela (Org.). A história dos índios no Brasil. São Paulo: Companhia das Letras, Secretaria Municipal de Cultura, FAPESP.

RIBEIRO, Darcy (1984 [1976]). Maíra. Rio de Janeiro: Civilização Brasileira. (1986). Utopia selvagem: saudades da inocência perdida, uma fábula. Rio de Janeiro: Record.

(1996). Os índios e a civilização: a integração das populações indígenas no Brasil moderno. São Paulo: Companhia das Letras.

RIBEIRO, João Ubaldo (1997). O feitiço da Ilha do pavão. Rio de Janeiro: Nova Fronteira.

RUDEL, Christian (2009). Réveils amérindiens: du Mexique à la Patagonie. Paris: Karthala.

SANTILLI, Márcio (2000). Os brasileiros e os índios. São Paulo: Senac.

SANTOS, Eloína Prati dos (2006). "A viagem do índio até a brasilidade: Antonio Callado, Moacyr Scliar, Assis Brasil e Antônio Torres". Letras de hoje, v. 41, n. 3 , p. $185-200$. 
SCLIAR, Moacyr (1997). A majestade do Xingu. São Paulo: Companhia das Letras.

(2002). Éden-Brasil. São Paulo: Companhia das Letras.

SOUZA, Márcio (1979). Teatro indígena do Amazonas. Rio de Janeiro: Codecri. (1980). Mad Maria. Rio de Janeiro: Civilização Brasileira.

(2001a). Crônicas do Grão-Pará e Rio Negro. v. 1. "Lealdade". Rio de Janeiro, São Paulo: Record.

(2001b). Crônicas do Grão-Pará e Rio Negro. v. 2. "Desordem”. Rio de Janeiro, São Paulo: Record.

(2005a). Crônicas do Grão-Pará e Rio Negro. v. 3. "Revolta". Rio de Janeiro, São Paulo: Record.

(2005b). A paixão de Ajuricaba. 2. ed. Manaus: Valer, Prefeitura de

Manaus, EDUA.

(2006). Ajuricaba, o caudilho das selvas. São Paulo: Callis.

(2009). História da Amazônia. Manaus: Valer.

SOUZA, Márcio et al. (1981). Os índios vão à luta. Rio de Janeiro: Marco Zero.

SOUZA, Márcio; BESSA, Ribamar (1981). "A questão indígena no Brasil". In: SOUZA, Márcio et al. Os índios vão à luta. Rio de Janeiro: Marco Zero.

THERIEN, Gilles (Dir.) (1995). Figures de l'indien. Québec: Typo.

THIERION, Brigitte Cavagnal (2010). Regards sur l'Amazonie: fiction, histoire, identité dans l'œuvre de Márcio Souza. Tese (Doutorado em literatura brasileira) - Université Rennes 2, Rennes.

TORERO, José Roberto; PIMENTA, Marcus Aurelius (2000). Terra Papagalli: narração para preguiçosos leitores da luxuriosa, irada, soberba, invejável, cobiçada e gulosa história do primeiro rei do Brasil. Rio de Janeiro: Objetiva.

TORRES, Antônio (2000). Meu querido canibal. Rio de Janeiro: Record

TREECE, David (2008). Exilados, aliados, rebeldes: o movimento indigenista, a política indigenista e o Estado-nação imperial. São Paulo: Nankin, Edusp.

Recebido em dezembro de 2011.

Aprovado em março de 2012.

\section{resumolabstract}

\section{Traumas e travessias: a alteridade ameríndia e as fronteiras}

simbólicas da nação

Rita Olivieri-Godet

Exame das questões relativas aos processos de apagamento e de resgate da memória, a partir de textos ficcionais que refletem sobre as negociações identitárias e as travessias de fronteiras culturais, centrados no ameríndio como instância de alteridade.

Palavras-chave: literatura brasileira contemporânea, alteridade, ameríndios, fronteiras 


\section{Trauma and crossings: Amerindian alterity and symbolic} boundaries of the nation

\section{Rita Olivieri-Godet}

Examination of issues related to the processes of extinguishment and retrieval of memory, through fictional texts dealing with both identity negotiations and crossings of cultural frontiers, focusing on Amerindians as instances of alterity.

Key words: contemporary Brazilian literature, alterity, Amerindians, cultural frontiers 